\title{
Toelating tot die bediening van die Woord met verwysing na die kerkorde van Dordrecht 1618 en 1619
}

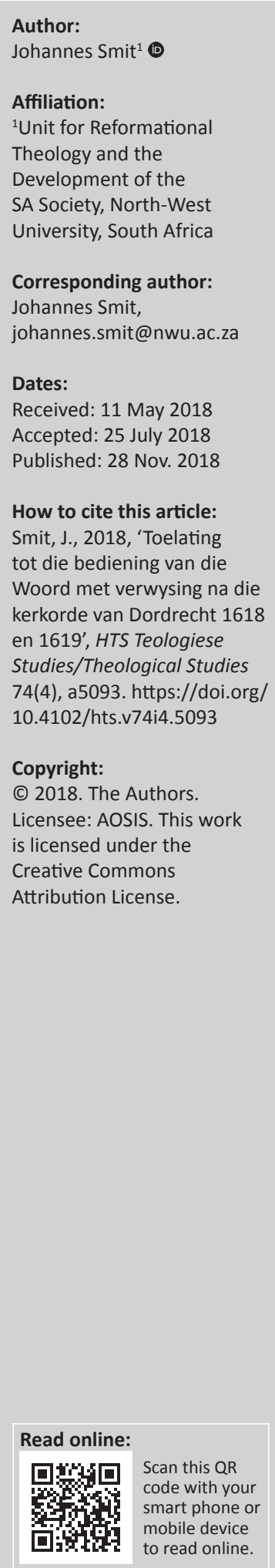

This article evaluates the terms and conditions candidates have to meet before entering into the ministry. This evaluation is then set against the background of reformed presuppositions about the office of a minister of the Word. The focus is especially on the relevant articles 4,8 and 9 of the Synod of Dordt, 1619. The article explains how the articles set out in the Church Order relate to a unique office (sui generis), namely that of the church minister. In the context of the Reformed Churches in South Africa, the practical application of these church order articles are also discussed. The question addressed is whether our understanding of the Church Order of Dordt, 1619, Article 8, represents a correct application of this church order article. Furthermore, this article illuminates the responsibilities of inter alia the curators of the Theological School Potchefstroom of the Reformed Churches in South Africa, as well as the responsibilities of the theological professors in the adjudication of application to become a minister of the Word in terms of the different church order articles.

\section{Inleiding}

Die gereformeerde tradisie stel in sy verskillende geledinge deur eeue heen 'n hoë premie op die teologiese opleiding as ' $n$ voorwaarde vir die toelating tot die bediening van die Woord. Die Reformasie het veral studie van die tale waarin die Bybel oorspronklik geskryf is, benadruk. In die gereformeerde tradisie word teologiese opleiding gewoonlik as 'n voorvereiste vir die toelating tot die diens van die Woord gestel. Dit geld vir alle persone wat van voorneme is om in 'n spesifieke gereformeerde kerkgemeenskap as bedienaar van die Woord te dien (KO Art 4 van die KO van Dordrecht, 1619; verder DKO), maar ook vir diegene wat moontlik reeds voorheen in 'n ander kerkgemeenskap as predikant gedien het (vgl. DKO Art 9). Kerkorde Artikel 9 veronderstel dat die aansoeker ten minste ' $n$ basiese teologiese onderrig by ' $n$ instansie ontvang het. Artikel 8 maak in dié verband voorsiening vir'n interessante uitsondering, naamlik dat persone met sogenaamde 'buitengewone' (singuliere) gawes sonder die vereiste opleiding, wat by alle ander aansoeke as voorwaarde sou geld, toegelaat kan word. Die bepaling is steeds by die Gereformeerde Kerke in Suid-Afrika (GKSA) in gebruik, maar nie by die Nederduitse Gereformeerde Kerk (NGK) of die Nederduitsch Hervormde Kerk van Afrika (NHK) nie. In die NGK is daar egter tans sprake van 'n nuwe verwikkeling in dié verband. Strauss (2016:1) wys daarop dat Artikel 8 van die Dordtse kerkorde moontlik in 'n bepaling van die kerkorde van die Nederduitse Gereformeerde Kerk (NGKO) beslag kan vind. Artikel 48.3.5 van NGKO-2011 bepaal dat 'n ouderling wat preekvergunning van die kerkraad en ring ontvang het, eredienste kan lei. Die bedoeling van Artikel 48.3 .5 is dat ' $n$ ouderling die volwaardige leiding van eredienste neem. Artikel 48.3.5 staan inhoudelik bekend as 'preekvergunning' (Strauss 2016:1). Dit verskil in dié opsig van die tradisionele 'leespreek', wat in die gereformeerde tradisie 'n geykte instelling is. Die bedoeling van 'n leespreek is nie om die bevoegdheid van die formele verkondiging van die Woord aan 'n persoon te verleen nie, maar om in spesifieke omstandighede die geleentheid te skep dat 'n goedgekeurde preek aan die gemeente gelees word (Strauss 2016:1). Daarmee ontvang die persoon nie die bevoegdheid om as predikant op te tree nie en mag daarom nie die seën voor en na die erediens uitspreek nie, en ook nie die sakramente bedien nie (Strauss 2016:1).

Die toelating tot preekvergunning, wat Strauss beskryf, dui ook op 'n verskil ten opsigte van die toelating van opgeleide predikante. In teenstelling met die toelating van gelegitimeerde, oftewel opgeleide, predikante waarvoor die toestemming/instemming van die Sinode en Algemene Sinode (die breë kerkverband) vereis word, is slegs die kerkraad en die ring betrokke by die toestaan van preekvergunning (NGKO 2011:2-3) (Strauss 2016:1). 
Die vraag wat ten grondslag van die hele kwessie lê, is die volgende: Wat is die agtergrond, vereistes en prosedures wat in terme van die onderskeie kerkorde artikels vir die toelating tot die bediening van die Woord gestel word? Die kerkorde artikels wat die toelating tot die diens van die Woord reël soos wat dit in die meeste standaardverklarings van die kerkorde weergegee word, het elkeen 'n unieke geskiedenis. Hierdie artikel het nie ten doel om daardie historiese aspekte te bespreek nie, behalwe waar dit moontlik spesifiek betrekking het. Artikel 8 beklemtoon egter dat die kerklike dienste gestalte is van 'n ander orde. Hierdie aspek van die diens sou soms verlore kon gaan, veral in die lig van 'n aanname dat die kerklike dienste vir die reëling daarvan de iure aan die staat se arbeidswetgewing onderworpe is. Daarteenoor handhaaf gereformeerdes en ander kerkregtelikes en regsgeleerdes uit verskeie teologiese tradisies en jurisdiksies dat Christus die diens van die Woord in die kerk gee. In dié opsig is dit tog insiggewend dat argumente wat hier aangebied word, hoewel dit soms in verskillende kerkregtradisies op verskillende wyses gefundeer word, daarop dui dat die diens van die Woord 'n eiesoortige (sui generis) aard het wat nie onder die reëlingsbevoegdheid van die staat in terme van, byvoorbeeld, arbeidswetgewing val nie (Smit 2005; vgl. Van Coller 2013a, 2013b). Die verantwoordelikheid vir die toelating, reëling en toesig oor die diens berus by die kerk en by geen ander instansie nie. Die redes vir hierdie bepaling word in die eerste deel van die artikel uiteengesit. Die fokus is hier op aspekte van die Calvinistiese beskouing van die diens van die bedienaar van die Woord.

Die tweede deel van die artikel gee 'n aanduiding van die kernaspekte van die onderskeie artikels wat die toelating tot die bediening reël, terwyl die derde deel op prosedures fokus wat handel oor die praktiese toepassing van die tersaaklike artikels, met spesifieke klem op die situasie in die GKSA.

Die Kerkorde van Dordrecht 1619 (DKO) waarna deurlopend verwys word, is die kerkorde wat by die GKSA in gebruik is, soos wat dit deur verskillende Sinodes van daardie kerkgemeenskap aangepas is. Dit is egter nie die enigste en belangrikste rede vir die verwysing na dié spesifieke kerkorde nie. Die kerkorde van Dordrecht 1618 en 1619 word in gereformeerde kringe as die hoogkonjunktuur van die gereformeerde kerkorde-ontwikkeling sedert die 16de eeuse Reformasie beskou. Dit het ook as 'n oriënteringspunt vir die verdere ontwikkeling van kerkordes in die gereformeerde tradisie gedien, ook in Suid-Afrika met inbegrip van die sogenaamde 'drie susterskerke'. Die Dordtse kerkorde van 1618 en 1619 bied in dié sin 'n aanknopingspunt vir kerke binne die gereformeerde tradisie vir gesprek en vergelyking wanneer dit gaan oor toelating tot die bediening van die Woord.

\section{Aspekte van toelating tot die bediening van die Woord wat ten grondslag lê van die kerkorde Johannes Calvyn - Een ryk met twee jurisdiksies}

Johannes Calvyn, die 16e eeuse hervormer van Genève, het die aandag daarop gevestig dat daar twee regeringsvorme in die mens teenwoordig is, naamlik die geestelike regering (regimen spirituale) en die burgerlike regering (regimen politicum; vgl. Du Plooy 1992:759 e.v.). Calvyn se beskouing sluit in sekere opsigte by Martin Luther se Twee Ryke-leer aan. Sy unieke beklemtoning lê egter daarin dat Calvyn se beskouing eerder as ' $n$ 'een Koninkryk-leer met twee jurisdiksies' beskryf sou kon word. Calvyn se opmerkings in hierdie verband moet gesien word in die lig van die omstandighede van sy tyd, spesifiek as 'n reaksie teen die beskouing van die wederdopers, wat hulle teen die burgerlike owerheid verset het (Calvyn, Inst. 4.20.2). Calvyn stel in dié opsig nie kerk en staat teenoor mekaar nie, maar stel die koninkryk van God as die vertrekpunt om die verhouding tussen die kerk en die staat te verstaan. God gee beide die geestelike en die burgerlike regering om die koninkryk van God daardeur te bevorder (Calvyn, Inst. 3, 19; 4.20.1; Du Plooy 1992:761-762). Die geestelike regering vestig in die mens se siel en rig die mens op die ewige lewe. Die politieke regering, daarenteen, handel oor die burgerlike lewe en het op die uiterlike regverdigheid van die sedes betrekking (Calvyn, Inst. 4.20.1). Calvyn sê aan die begin van Boek IV van die Institusie, Hoofstuk 20, dat ons hierdie twee regerings wat heeltemal van mekaar verskil, '[nie] onverstandig moet vermeng ... nie' (Calvyn, Inst. 4.20.1). Calvyn oordeel verder dat die burgerlike regering nie deur die geestelike regering opgehef word nie, maar dat dit temas is wat baie van mekaar verskil (Calvyn, Inst. 4.20.1). By Calvyn is daar nie sprake van 'n vergeestelikte kerk of ampsbegrip nie. Die kerkregering vind konkreet in hierdie wêreld gestalte. Calvyn verduidelik dié regering, d.w.s. die geestelike regering, uitvoerig in die eerste deel (hoofstukke 1-19) van boek IV van die Institusie.

Die regering wat Calvyn vir die kerk aandui, sentreer rondom die besondere dienste wat Christus aan sy kerk gee - by wyse van die bediening van die Woord word die Christusregering in die kerk verwesenlik. Die orde van die kerk, soos dit by Calvyn uitdrukking vind, is fundamenteel anti-hiërargies. Hierdie beginsel van die 16de-eeuse Reformasie, soos dit reeds deur Luther aangedui word, gee uitdrukking aan die prinsiep dat geen ander vorm van regering behalwe die Christusregering in die kerk behoort te geld nie. Dit bied reeds ' $n$ aanduiding dat die bediening van die Woord eiesoortig is. Die kerk, as die herstelde mensheid in Christus, word by wyse van die verkondiging in die wêreld vergader en opgebou. Die bediening van die Woord staan dus sentraal in hierdie godsdienstige orde.

\section{'n Godsdiensbepaalde orde}

Calvyn het nie prinsipieel van Luther se uitgangspunt verskil nie. Alhoewel albei die beginsel van die onsigbare kerk (ecclesia abscondita) onderskryf, val die klem by Calvyn anders as by Luther. Calvyn onderskei tussen die ecclesia universalis [universele kerk] en die ecclesia particularis [plaaslike kerk]. Calvyn lê egter die klem daarop dat die kerk ook sigbaar is. Die kerk vind in hierdie bedeling veral in sy plaaslike uitdrukkingvorm, gestalte (Van't Spijker 1990:329 e.v.). Hoewel slegs Christus oor die harte van 
mense kan oordeel, werk die Gees op so 'n wyse vrugte in die gelowige dat dit onmiskenbaar aan die kerk in die wêreld gestalte gee (vgl. Smit 1997). Hierdie kerk vind naamlik in die wêreld rondom die verkondiging van die Woord en die bediening van die sakramente uitdrukking. Vir Calvyn is die kerk tegelyk sigbaar en onsigbaar. Die kerk is egter ook in sy sigbare gestalte onder die hoofskap van Christus georden (vgl. Van't Spijker 2004:179). Calvyn meen dat die kerk sy eie regering en dissipline handhaaf. Geen instansie naas die kerk het die bevoegdheid om hierdie regeringsrol te vervul nie en slegs Christus regeer oor die kerk (Calvyn, Inst. Boek IV). Hierdie beginsel sou ook anders geformuleer kon word: Christus is die enigste Hoof van die kerk en dra nie sy gesag om die kerk te regeer aan ' $n$ persoon of instelling oor nie. Die Woord staan dus sentraal in die denke van hierdie hervormer. Die regering van Christus vind sigbaar in die wêreld gestalte by wyse van die bediening van die Woord. Dit hou verband met die Nuwe Testamentiese begrip van orde. 'n Enkele aspek van van dié orde wat hier van belang is, is die kernbetekenis van die woord 'orde', naamlik dat 'iets of iemand herstel is om op sy Godgegewe plek te funksioneer' (Smit 1984:18). Dit geld uiteraard vir die kerk, wat deur God in Christus herstel is om 'n nuwe lewe in Christus te voer met inbegrip van die besondere dienste wat deur Christus in die kerk gegee word tot opbou van die kerk in die uitvoering van haar taak in die kerk en die samelewing.

\section{Pneumatologiese orde}

Calvyn verwerp die Rooms Katolieke kerk se beskouing van die amp op grond daarvan dat dit een besondere kenmerk van dieNuwe Testamentiese amp misken, naamlik die pneumatiese ordeningsbeginsel (pneumatische Ordnungsprinzip) (Bohatec 1961:448, 560). Josef Bohatec (1961) het in sy omvattende studie, Calvins Lehre von Staat und Kirche, wat vandag steeds as 'n standaardwerk beskou word, aangedui dat Calvyn se kerkregering, soos die ander aspekte van sy teologie, enkapties met sy leer van die Heilige Gees (pneumatologie) vervleg is. Calvyn se beskouing van die Christusregering hoort by sy leer van die Gees. Christus regeer die kerk deur sy Woord en Gees, en werk juis deur Sy Gees in ons. Op dié wyse word die Christusregering in die mens voltrek. Die Gees in nobis [in ons] rig ons voortdurend op Christus extra nos [buite ons] aan die regterhand van die Vader. Die gevolg daarvan is dat hoe meer die Gees in ons word, hoe minder word ons in onsself (Van't Spijker 1991:114-132). Dit geld dan opsigself ook van die Christusregering in ons. Deur die werking van die Heilige Gees word die regering van Christus vir die gelowiges 'n werklikheid. Dit gebeur deur die bediening van die Woord. Die orde wat Christus vir hierdie bediening daarstel, realiseer daarin dat hy mense in sy diens betrek en sy liefde vir hulle op hierdie wyse aan hulle bekend maak (vgl. 2 Kor 5:20; Calvyn Inst. 4.3.1). Hierdie regeringswyse kan óf as 'n regeringswyse óf as 'n kerklike orde van die bediening (verkondiging) van die Woord beskou word. Wie tot die diens van die Woord toegelaat word, verbind hom aan hierdie godsdienstige orde; die bedienaar van die Woord is nie slegs aan 'n godsdienstige orde verbind nie, maar word 'n sleutelfiguur in die vestiging, die opbou en uitdra daarvan. Die predikant onderwerp hom dus nie slegs aan 'n godsdienstige orde nie, maar is vanweë die aard van sy diens deel van die godsdienstige orde wat by wyse van die bediening van die Woord in die wêreld gestalte vind.

\section{Bevoegdheid van die kerk}

Calvyn het daarop gewys dat die regimen spirituale en regimen politicum nie met mekaar vermeng moet word nie. 'n Belangrike onderskeid tussen die Lutherse en die Calvinistiese kerkbeskouing berus daarop dat die kerk volgens die Lutherse beskouing 'n kultusgemeenskap is, maar Calvyn beskou die kerk as 'n lewensgemeenskap, 'n sosiale organisme (Bouwman 1970:232-233). Die staatsregering het nie die verantwoordelikheid om 'n orde vir die kerk daar te stel en te onderhou nie. Die kerk het sy eie bevoegdheid (Calvyn, Inst. 4.8.1, 4.11.1; Plomp 1969:63, 73). Dit behels, volgens Calvyn, dat die kerk beskik oor potestas doctrinae (die bevoegdheid om te onderrig), potestas jurisdictionis [die bevoegdheid om te regeer] en die potestas in legibus ferendis [die bevoegdheid om wette te maak]. Die potestas doctrinae dui daarop dat die kerk die bevoegdheid het om sy leer ooreenkomstig die Skrif te formuleer. Die konfessie is homologein, om die Skrif na te sê. Die bedoeling daarvan is dat die kerke almal saam uitdrukking gee aan die kernbeginsels van hulle gemeenskaplike geloof. Die potestas jurisdictionis dui daarop dat die kerk die bevoegdheid het om die nodige bepalings daar te stel vir die uitvoering van sy taak. Sonder om deur 'n veralgemening aan die omvang daarvan afbreuk te doen, kan hierdie bevoegdhede opgesom word as die kerk se bevoegdheid om die geestelike regering in die wêreld by wyse van die verkondiging van die Woord te behartig. Die uiteensetting hierbo maak dit duidelik dat die bediening van die Woord sentraal staan binne hierdie bevoegdheid.

\section{Wyse van funksionering}

Die kerk is die gemeenskap wat deur die verkondiging van die Woord in hierdie wêreld vergader word. Die orde wat Christus vir sy kerk daarstel, vind sy oorsprong ten diepste in die roeping wat van God deur sy Seun, Jesus Christus, uitgaan. Deur die verkondiging van die Woord realiseer hierdie goddelike roeping. Dieselfde geld ten opsigte van die besondere dienste in die gemeenskap van die geroepenes. In die kerk roep Christus mense op 'n besondere wyse tot Sy diens. Deur die roeping, aktiveer Hy die gawes wat Hy aan sy diensknegte gee om die kerk op en uit te bou. Roeping, gawe en diens is inherent aan mekaar verbind. Christus bepaal ook die taak van die geroepe bedienaars. Hierdie taak staan onder alle omstandighede sentraal tot die verkondiging van die Woord. Op dié wyse word die kerk deur die besondere dienste opgebou, maar ook in staat gestel om in die gang van die lewe, te midde van gelowiges se alledaagse bestaan, die uitbou van die kerk te behartig.

\section{Hersiening van kerklike besluite}

Die kerk bly in hierdie bedeling aan sonde en onvolmaaktheid onderhewig. Dit sou dus moontlik wees dat kerklike 
handelinge en besluite deur 'n burgerlike hof hersien kan word. 'n Burgerlike hof het egter nie die bevoegdheid om vir 'n kerk te bepaal wie tot die interne dienste toegelaat word nie, en ook nie om iemand in daardie dienste te herstel nie. Hierdie bevoegdheid berus uitsluitlik by die kerk en die staat het geen seggenskap oor die inhoudelike aspekte van die geestelike regering nie. Dit gee egter nie aan die kerk 'n vrypas om na willekeur teenoor mense op te tree nie. Die Skrif stel die norm waaraan alle kerklike optrede moet voldoen. Die beginsels van reg en billikheid geld dus op presies dieselfde manier in alle omstandighede, ongeag die feit dat dit op ' $n$ ander wyse verpak kan wees as binne staatlike wetsbepalings. Bowendien, die kerk moet in sy regering gehoorsaam wees aan die hoogste eis wat die Skrif stel, naamlik dat die liefde in sy handelinge gestalte vind. Dit gebeur wanneer die kerk die waarheid van die Evangelie nastreef en in sy kerkregering binne die eis van die liefde handel. Reg, waarheid en liefde staan nie teenoor mekaar nie, maar moet juis in die kerkreg in ewewigtige verhouding tot mekaar gestel word in gehoorsaamheid aan die eis van die Woord. In die toepassing van hierdie orde vervul die predikant 'n sentrale rol.

'n Bedienaar van die Woord moet as voorsitter van 'n kerklike vergadering optree (KO art 35). Die vraag is nie in die eerste plek of 'n ander persoon ' $n$ beter voorsitter sou wees nie. Die taak van die voorsitter is om die vergadering ooreenkomstig die Woord te lei; die persoon wat as voorsitter optree, behoort die Woord op so 'n wyse te bedien dat Christus in der waarheid die vergadering deur middel van sy Woord en Gees lei (Calvyn, Inst. 4.9.1). Die predikant, as voorsitter, het die verantwoordelikheid om toe te sien dat die vergadering ooreenkomstig die Woord funksioneer (vgl. Spoelstra 1989:215 e.v.). Die verantwoordelikheid van 'n voorsitter van 'n kerklike vergadering behels dus veel meer as ' $n$ vorm van prosesbestuur om 'n demokratiese uitkoms vir die vergadering te verseker. Die voorsitter moet ook die Christusregering dien deur die verkondiging van die Woord, sodat die Gees só ook in die vergadering regeer. Oor die Woordbediening behoort ' $n$ burgerlike hof nie seggenskap te hê nie. Dit is wel moontlik, soos al in die verlede in Suid-Afrika gebeur het, dat die howe by wyse van ' $n$ hersiening aan kerkgemeenskappe uitwys dat hulle nie aan die spesifieke kerkorde of interne prosedure van die kerkgemeenskap gevolg gegee het nie. 'n Burgerlike hof het egter nie die bevoegdheid om ' $n$ kerklike bedienaar in sy diens te herstel nie. Die bevoegdheid om oor die bekwaamheid van kerklike bedienaars te oordeel en hulle tot die kerklike dienste toe te laat, berus uitsluitlik by die kerke. Uiteraard behoort kerke foutiewe optrede in dié verband reg te stel.

\section{Fokuspunte van KO Artikels 4, 8, 9 Artikel 4 - Roeping en ander aspekte van die diens onderliggend aan die toelating tot die bediening van die Woord}

Kerkorde Artikel 4 reël die normale of geykte weg vir die toelating tot die bediening van die Woord. Die fokus van Artikel 4 is egter nie, soos daar soms aanvaar word, op die studie wat die toelating tot die diens voorafgaan nie, maar wel op die roeping tot die diens. Die artikel handel oor die twee afsonderlike fasette van die roeping, naamlik die inwendige en die uitwendige roeping, en reël die wyse waarop die innerlike roeping by wyse van die uiterlike roeping bevestig word. In die ontwikkeling van die innerlike roeping en die bevestiging daarvan speel die teologiese opleiding ' $n$ belangrike rol. Dit word beskou as ' $n$ aanduiding daarvan dat die gawes en middele (ook op 'n materiële vlak) wat die Here aan ' $n$ persoon voorsien om te kan studeer as 'n bevestiging van die innerlike roeping dien. Die bedienaar van die Woord word op dié wyse deur die Here as 'n gawe in sy kerk gegee. Hierdie gawe word by wyse van die roeping tot die diens in die kerk geaktiveer en vind as 'n diens in die kerk (plaaslike kerk) uitdrukking (vgl. Smit 2001:17 ev.; 25 e.v.). Kerkorde Artikel 4 stel dit duidelik dat die kerk seggenskap oor die roeping van die bedienaars het en dat die kerkorde hierdie roeping reël.

Die opleiding van 'n bedienaar vorm deel van die bevestiging van die innerlike roeping soos dit hieronder uiteengesit word. Dit is insiggewend dat die kerkorde nie die wyse van opleiding of die aard van die opleiding, byvoorbeeld 'n kerklike opleiding, 'n universiteitstudie of 'n kombinasie daarvan, reël nie (vgl. KO Art 4). Die Dordtse kerkorde dateer uit 'n era waarin teologiese opleiding aan 'n erkende instelling nie algemeen toeganklik was nie. Protestantse kandidaatstudente kon aanvanklik slegs by Heidelberg, Genève of Leiden (sedert 1575) studeer. Onder hierdie omstandighede is die opleiding wat predikante aan persone gegee het ná die nodige kerklike evaluering as voldoende erken. Die gereformeerde kerke ken 'geen anderen weg tot de bediening des Woords dan die der theologische studiën' (Bouwman 1970:400). Hoewel die moontlikhede van reformatoriese teologiese studie reeds tydens die Reformasie uitgebrei het, is die kerkorde nie op hierdie punt verander nie. Die kerkorde bied dus die vryheid aan kerkgemeenskappe om by wyse van sinodebesluite die nodige reëlings oor die opleiding in 'n spesifieke situasie te tref en die vereistes wat daarvoor geld, te spesifiseer. Tans is kerkgemeenskappe gewoonlik in 'n posisie om van universitêre opleiding gebruik te maak, hoewel dit nie onbekend is dat kerke dan steeds vir denominasie-bepaalde opleiding voorsiening maak nie. Die gebruik van teologiese seminariums vir die volle of gedeeltelike opleiding van bedienaars van die Woord is tans goed bekend.

Artikel 4 reël die toelating tot die diens. Dit geskied by wyse van 'n eksaminering deur die kerke. In die gereformeerde tradisie is dit geyk dat daar tussen 'n praeparatoire [voorbereidende eksamen] en 'n peremptoire [beslissende eksamen] onderskei word. Bouwman (1970:398 ev.) gee 'n verduideliking van hoe die praeparatoire en die peremtoireeksamens ontwikkel en in die kerkorde opgeneem is (vgl. Acta 1970:123-125).

Die Dordtse kerkorde (1619) het aanvanklik slegs voorsiening gemaak vir die peremtoire-eksamen. In hierdie eksamen moes 
die kandidaat bewys dat hy aan die kernvereistes vir die toelating tot die diens voldoen. Daaruit blyk onder meer soos volg:

1. Geen ander instelling buiten die kerkehet die bevoegdheid om oor die roeping van 'n voornemende bedienaar van die Woord, en daarom oor toelating tot die bediening van die Woord, te oordeel nie (vgl. Spoelstra 1989:40, 44). Slegs die kerke, en spesifiek die plaaslike kerk (gemeente), het die bevoegdheid om toesig oor die prediking te hou.

2. Daar moet egter ook in gedagte gehou word dat opleiding nie die enigste aspek is waaroor kerke tydens die toelating tot die diens van die Woord oordeel nie. Opleiding vorm 'n belangrike deel van die innerlike roeping, maar ander aspekte, soos byvoorbeeld godsaligheid, ootmoedigheid en ingetoënheid, goeie verstand en onderskeidingsvermoë sowel as gawes van welsprekendheid, wat in Kerkorde Artikel 8 uitgespel word, is ipso facto by die toelating tot die bediening van die Woord, in terme van Kerkorde Artikel 4, van toepassing. Dit vorm eweneens deel van die kerke se beoordeling van die innerlike roeping.

3. Die kerkorde reël, soos hierbo aangedui is, die roeping van 'n predikant. In die beoordeling van die roeping, staan meer kerke mekaar by. Die kerkorde bepaal dat 'n beoordeling van die predikantsdiens, oftewel die roeping van 'n predikant, met die advies van meer kerke plaasvind. Die uitgangspunt is dat meer kerke mekaar bystaan in die beoordeling van ' $n$ predikant se roeping (vgl. KO Art 4-17). Met die toelating tot die diens oordeel meer kerke saam oor die roeping. Meer kerke staan mekaar ook by in dié beoordeling tydens ' $n$ predikant se bediening, óf met sy moontlike verlating van die diens. Die kerke het die verantwoordelikheid om, in die lig van al die beskikbare getuienis, oor die roeping van 'n kandidaat te oordeel. Dit bepaal of 'n persoon geskik is om in die kerke te dien.

\section{Artikel 8 - Buitengewone gawes}

Die aspekte wat vir die diens geld, soos dit hierbo aangedui is, is mutatis mutandis op Kerkorde Artikel 8 van toepassing. Artikel 8 handel egter oor 'n situasie waar 'n persoon die nodige gawes sou hê om tot die diens van die Woord toegelaat te word, sonder dat sodanige persoon in die teologie gestudeer het. Op dié wyse gee die kerkorde, behalwe van Artikel 4, aan die beginsel uitdrukking dat die Here self mense tot sy diens roep en hulle daarvoor bekwaam (Visser 1999:43). Kerkorde Artikel 8 behoort daarom as 'n belydenis binne die kerkorde gesien te word. Dit gee uitdrukking aan die soewereiniteit en vrymag van God. God kan ook buite-om die gewone pad van kerklike opleiding 'n persoon tot sy diens roep en hom daarvoor bekwaam maak (Kruger et al. 1966:78; Van der Linde 1983:37-38). Die geskiedenis gee hierop perspektief.

Die kerke het veral in tye van nood ervaar dat daar op 'n buitengewone wyse bedienaars van die Woord aan die kerke voorsien is (Kruger et al. 1966:78). In tye van oorlog, vervolging en pestilensie het persone na vore getree wat in terme van Kerkorde Artikel 8 as 'n predikant sou kon dien. Die argument dat die kerke in ' $\mathrm{n}$ tyd van 'nood' verkeer, word tans ook gebruik. Die nood vind blykbaar daarin uitdrukking dat kerkgemeenskappe besig is om te krimp. In baie gevalle ervaar kerke ' $n$ tekort aan bedienaars van die Woord. Artikel 8 word dan by die gesprek betrek omdat dit die moontlikheid sou kon skep om 'n persoon tot die diens toe te laat sonder dat die kandidaat aan die vereiste van 'n uitgerekte studie voldoen. Die kern van die saak gaan egter in die redenasie verlore. Artikel 8 wys op 'n situasie waar die nood in die kerke (en in die samelewing) van só 'n aard sou wees dat dit nie vir 'n persoon moontlik is om hom by wyse van die geldende bepalings t.o.v. teologiese studie vir die diens van die Woord te bekwaam nie. Die kerke wend hulle dan tot die moontlikheid dat die vereiste teologiese studie opgehef word (Kruger et al. 1966:78).

Kerkorde Artikel 8 stel die volgende reël: 'Iemand wat nie gestudeer het nie, sal nie tot die diens van die Woord toegelaat word nie'. Positief gestel: Iemand moet studeer om tot die diens van die Woord toegelaat te word. Aan hierdie bepaling word daar oor die algemeen te min aandag gegee. In terme van Artikel 8 is die vereiste nie in die eerste plek dat 'n aansoeker sy buitengewone gawes behoort aan te dui nie. Inteendeel, die onus berus op 'n aansoeker om aan te dui waarom hy in die omstandighede nie kan studeer nie. Dit is die reël wat tans geld. Verder maak Artikel 8 eweneens nie 'n deur oop vir persone om as sogenaamde 'kortbroek' predikante op te tree nie - dié term verwys na predikante wat nie die nodige opleiding vir die diens voltooi het nie. Artikel 8 maak nie 'n onderskeid tussen ten volle bekwaam vir die diens en slegs gedeeltelik bekwaam nie. 'n Predikant is volgens die aard van sy roeping ten volle in diens van Christus. Sy diens en die mandaat om dit uit te oefen, berus eweneens by Christus. In die Nuwe Testament is daar nie sprake daarvan dat bedienaars gedeeltelik in die diens van Christus staan nie. Die kerke het die verantwoordelikheid om hulle daarvan te vergewis dat' $n$ persoon oor die buitengewone gawes beskik waarop hy aanspraak maak. Maar wat is die 'buitengewone' gawes waarna Artikel 8 verwys?

Artikel 8 bepaal tans oor die gawes soos volg: '[T]ensy daar sekerheid is van sy buitengewone gawes, godsaligheid, ootmoedigheid en ingetoënheid, goeie verstand en onderskeidingsvermoësowelas gawes van welsprekendheid'. Die vraag is egter of daar eerder 'n dubbelpunt (:) na 'buitengewone gawes' geplaas behoort te word. Indien die dubbelpunt ingevoeg word, sou dit beteken dat die term 'buitengewone gawes' as versamelnaam vir hierdie soort gawes dien; dit is dan slegs die 'buitengewone' gawes wat ná die dubbelpunt genoem word. Kerkregtelikes in die gereformeerde tradisie is van mening dat die invoeging van die dubbelpunt ' $n$ beter of selfs korrekte vertaling van die Latynse teks daarstel (vgl. Bouwman 1970:438; De Gier 1989:Art. 8; Jansen 1952:41-42; Kruger 1966:78-79; Spoelstra 1989:73; Strauss 2016:2-3). Myns insiens gee die eksakte vertaling van die Latyn nie noodwendig die kern van die saak korrek weer nie, aangesien die bedoeling eerder as die 
letterlike betekenis in die vertaling nagestreef moet word. Die volgende aspekte behoort daarby verder oorweeg te word:

- Indien die Sinode van Dordrecht 1618 en 1619 die dubbelpunt as 'n kernaspek beskou het, sou dit uit die hersiening van die kerkorde geblyk het. Die Sinode het die geleentheid gehad om die onsekerheid oor die vertaling uit die weg te ruim, maar het nie daarvan gebruik gemaak nie. Ons kan daarom aanvaar dat die teks van die kerkorde (Dordrecht 1619), waar die dubbelpunt nie ingevoeg is nie, die bedoeling van die Sinode korrek weergee.

- Indien die dubbelpunt ingevoeg word, beteken dit dat die gawes ná die dubbelpunt die enigste gawes sou wees wat in terme van 'n Kerkorde Artikel 8 aansoek as 'buitengewoon' sou geld. Die gawes wat in Kerkorde Artikel 8 genoem word, is sonder twyfel belangrike gawes wat 'n bedienaar van die Woord behoort te hê. Artikel 8 verwys spesifiek na die gawes van pietas [vroomheid, Godsaligheid], humilitas [nederigheid; ootmoedigheid], modestia [dissipline; selfbeheersing], en prudentia [diskresie, die gawe van onderskeiding] (vgl. Jansen 1952:42 e.v.) Dit behoort egter nie as die enigste gawes beskou te word waaroor 'n persoon wat bedienaar van die Woord sal wees, moet beskik nie. Elke persoon wat om toelating tot die diens aansoek doen, behoort van hierdie gawes rekenskap te kan gee. Dit is goed bekend dat die gawe van excellens ingenium [goeie verstand] en eloquentia [welsprekendheid], wat in Kerkorde Artikel 8 as deel van die lys van gawes genoem word, nie noodwendig beteken dat ' $n$ persoon die gawe het om te preek nie (vgl. Jansen 1952:42 e.v.). Tog word die gawe van die prediking nie in die lys van gawes opgeneem nie. Die kerkorde tref egter' $n$ reëling om die gawe van prediking te toets. Daaruit blyk dat die bogenoemde gawes teenwoordig moet wees as ondersteuning ter wille van die diens van die prediking. Die saak waaroor dit in Artikel 8 gaan, word daarmee ondervang: 'n Persoon moet die gawes hê om die Woord van die Here te verkondig. Die oorkoepelende vraag wat in terme van $\mathrm{KO}$ Artikel 8 geld en beantwoord moet word, is of die persoon die roeping en gawes het om die Woord op 'n konstante basis eksegeties korrek (sonder kennis van die grondtale) binne die raamwerk van die openbaringshistoriese gegewens uit te lê en toe te pas (KO Art 4, 5; vgl. Spoelstra 1989:74; Visser 1999:43). Die gawes wat in Artikel 8 genoem word, behoort daarom as ondersteunend tot die verkondiging van die Woord beskou te word, maar moet nie as die enigste vereistes vir woordverkondiging dien nie.

- In die kerkorde-ontwikkeling sedert Calvyn word aanvaar dat dit nie nodig is om uitgebreide lyste in 'n kerkorde op te neem nie. Calvyn se uitgebreide vereistes vir toelating tot byvoorbeeld die nagmaal, die huwelik, en die bekende 'sondelys' van Kerkorde Artikel 80 (in die kerkorde van Dordrecht 1618/19), is in die era van kerkorde-ontwikkeling (sedert die bydraes van Bucer en Calvyn tot en met die Sinode van Dordrecht 1618 en 1619) aansienlik verkort (vgl. Pont 1981:22 e).
- Kerkregtelikes aanvaar dat die historiese ontwikkeling daarop dui dat die kerkorde, waar dit van toepassing sou wees, met enkele voorbeelde oor die tersaaklike aangeleentheid volstaan. Hierdie ontwikkeling behoort ook met die lees van Artikel 8 in ag geneem te word. Artikel 8 stel die kern van die saak waarom dit gaan aan die orde sonder om 'n volledige lys van gawes daar te stel of om op sodanige lys aanspraak te maak.

Op grond van die bogenoemde argumente behoort die buitengewone gawes as 'n kategorie naas die ander gawes verstaan te word. Daarmee is Artikel 8 in dié opsig onlosmaaklik aan Artikel 4 verbind. Artikel 4 handel oor die roeping tot die formele diens van die Woord, wat op die gawes dui om die Woord in alle omstandighede ter wille van die opbou van die kerk en die uitbou van die koninkryk te bedien. Artikel 8 onderskryf die reëling van die roeping ten volle, maar behandel 'n situasie waar 'n persoon die vermoë sou hê om die Woord in sy volle omvang in enige omstandighede te verkondig sonder dat hy die voorgeskrewe teologiese studie voltooi het om hom daarvoor toe te rus.

\section{Artikel 9}

Die vereistes wat vir die bediening geld, soos dit hierbo aangedui is ten opsigte van Artikel 4, is mutatis mutandis op Kerkorde Artikel 9 van toepassing. Artikels 8 en 9 reël beide 'n uitsondering op die reël oor die toelating tot die bediening van die Woord. Die gemeenskaplike aspekte van Artikels 8 en 9 behoort daarom saam gelees te word (Spoelstra 1989:80). Die kernverskil tussen die artikels is egter duidelik. Artikel 8 plaas die fokus op 'n persoon wat buitengewone gawes sou hê, maar Artikel 9 op die moontlike toelating van predikers wat van 'ander kerke of een of ander sekte' as bedienaar van die woord in die GKSA wil optree. Die gewone weg van toelating tot die bediening het in die reël dus reeds vir 'n Artikel 9 aansoeker gegeld, naamlik die weg van teologiese opleiding. Kerkorde Artikel 9 stel die reël wat in daardie omstandighede vir die toelating tot die diens geld: 'Predikers wat uit ander kerke of een of ander sekte aansluit, sal nie tot die kerkdiens toegelaat word nie'. In die ontwikkeling van die kerkorde het verskillende Sinodes bepaal dat priesters, monnike, dopers, en diesulkes wat begerig is om na die gereformeerde kerke oor te kom, eers deeglik getoets behoort te word. Die Sinode van Dordrecht 1618/19 het by artikel 9 die term 'nuwelinge' ingevoeg. Dit verwys na 1 Timoteus 3:6, waar Paulus daarop wys dat' $n$ nuweling nie tot die diens van die Woord toegelaat mag word nie. 'Hy moet nie 'n nuweling wees nie, sodat hy nie verwaand word en in dieselfde oordeel as die duiwel val nie'. Dit geld ook ten opsigte van Artikel 4, 8 en 9 kandidate vir die bediening.

Soos in die geval van Artikel 8, bied Artikel 9 nie 'n sogenaamde kortpad vir 'n persoon om tot die diens van die Woord toegelaat te word nie. Artikel 9 skep die moontlikheid dat 'n persoon wat ' $n$ bedienaar van die Woord in ' $n$ ander kerkgemeenskap of sekte was, in die kerke as predikant sou kon dien. Die uitgangspunt kan na Calvyn se beskouing van die kerk en die diens herlei word. Dit dui daarop dat die 
kerk van Christus oor die hele aarde en in verskillende kerkgemeenskappe versprei is (Calvyn, Inst. 4.1.7). Op dié wyse word daar ook aan die noodsaaklike plek van die diens van die Woord in die kerk uitdrukking gegee. Die kerk is daar waar die Woord suiwer verkondig en die sakramente bedien word. Daarby haak die tug organies in as die wyse waarop die toegang tot die tafel van die Here gereguleer word. Die kerk is oor die hele wêreld versprei en vind rondom die suiwer verkondiging van die Woord uitdrukking. Diegene wat die roeping en die gawes het om die Woord suiwer te bedien, sou dus in terme van Artikel 9 ook in die kerke waarop die $\mathrm{KO}$ betrekking het, opnuut tot die diens van die Woord toegelaat kon word.

Artikel 9 erken op dié wyse die roeping van bedienaars van die Woord in 'n wyer kring as 'n enkele kerkgemeenskap. Dit gee egter nie 'n vrye toegang vir enige predikers tot die preekstoel in gereformeerde kerke nie. 'n Persoon, wat in terme van Artikel 9 aansoek om die bediening van die Woord in die kerke doen, se aansoek word as 'n nuwe aansoek beoordeel. Die aansoek word de novo beoordeel. Die kerklike amp het volgens die gereformeerde beskouing nie 'n sogenaamde 'onvernietigbare' karakter (character indelibilis), soos wat die Rooms Katolieke kerk beweer, nie (vgl. Bouwman 1970:128, 156, 409, 420, 461, 610). Volgens Rome is die amp 'n status, 'n posisie wat nie verlore gaan wanneer 'n persoon dit eenkeer verwerf het of daartoe toegelaat is nie. Dieselfde gedagte van 'n ampstatus funksioneer ewe gemaklik in die kollegialisme, wat in ons tyd endemies aan die kerk en ampsbeskouing in Suid-Afrika is (vgl. Smit 2018). 'n Prediker kan egter nie op grond van sy sogenaamde amp daarop aanspraak maak om die Woord in die kerke te bedien nie. Die nodige toetsing moet plaasvind voordat die kerke sodanige persoon tot die diens van die Woord toelaat (KO Art 4). In beginsel geld dieselfde waar die sogenaamde 'kanselruil' tussen, byvoorbeeld, die histories-gereformeerde kerke in Suid-Afrika sou plaasvind. Die plaaslike kerkraad is verantwoordelik vir die toesig oor die prediking en dus wie tot die kansel toegelaat word. Die kerkraad mag slegs 'andere prediker' tot die verkondiging van die Woord toelaat oor wie se regsinnigheid en goeie trou daar van sekerheid is (Acta 1882:34).

Die feit dat die aansoeker wel voorheen 'n predikant was, kan vir die kerke 'n aanduiding van die roeping van die persoon gee. Die roeping is immers voorheen reeds bevestig. Laasgenoemde behoort tydens ' $n$ aansoek in ag geneem te word. 'n Aansoeker se opleiding sou in sekere gevalle, byvoorbeeld, nie met die opleiding in die GKSA vergelykbaar hoef te wees nie. Dit hef egter nie opsigself die moontlikheid op dat' $n$ persoon in terme van Artikel 9 tot die diens toegelaat kan word nie. Die belangrikheid van teologiese opleiding vir die toelating tot bediening van die Woord staan in die gereformeerde of selfs protestantse tradisie voorop, maar dit mag ook nie ten alle koste vereis word nie (Spoelstra 1989:79). 'n Persoon sou, byvoorbeeld, vir die diens in 'n spesifieke kerkgemeenskap 'n 'mindere' opleiding kon ontvang, maar op grond van insig in die Woord, lewenservaring, en ander bekwaamhede tog blyke gee van die nodige gawes om die roeping in die kerke op te volg (Spoelstra 1989:79). Dit sou daarom nie moontlik wees om vir elke moontlike mutasie op die reël by wyse van ' $n$ ordebepaling voorsiening te maak nie, aangesien die beoordeling van ' $n$ Artikel 9 aansoek die mens in sy geheel beoordeel op grond van die aanduiding van roeping en gawes. Dit dui op 'n proses wat op goeie oordeelsvermoë van die kerke behoort te berus.

\section{Die Teologiese Skool Potchefstroom- Senaat (TSP) \\ Prosedures}

Kerkorde Artikel 4 - In terme van Artikel 4 geld die volgende besluit vir persone wat hulle vir kandidaatstudie aan die TSP aanmeld:

'Die ideale situasie is dat voornemende predikante hulle volledige opleiding in Potchefstroom doen. Waar nodig (soos bepaal deur studente se persoonlike omstandighede of die behoeftes van kerke) kan daar egter voorsiening gemaak word dat studente hulle Kandidaats I-III buite Potchefstroom aan een van die erkende instellings doen of deur middel van telematiese studie, met die Kandidaats IV-VI in Potchefstroom. Uitsondering op hierdie ideale situasie is moontlik en kan op ' $\mathrm{n}$ ad hoc-basis deur die Kuratore gereël word' (Acta 2006:799).

Die aangehaalde sinodebesluit bevat die terme 'ideale' situasie en 'volledige' opleiding. Die ideaal wat die Sinode stel, is dat alle kandidaatstudente voltyds by die TSP in Potchefstroom opgelei word. Twee uitsonderings is egter op hierdie besluit moontlik. (1) Studente sou hulle Kandidaats I-III studie buite Potchefstroom op die gespesifiseerde wyses kon afhandel indien spesifieke omstandighede, soos in die besluit genoem word, dit nodig maak. (2) Verder geld die reël dat die Kandidaats IV-VI studie in Potchefstroom voltooi word. ' $n$ Uitsondering op hierdie ideale situasie is 'moontlik en kan op 'n ad hoc-basis deur die Kuratore gereël word'.

Die sinodebesluit gee die ruimte aan die Kuratore om op 'n ad hoc-basis te oordeel of die nagraadse studie van 'n student op 'n ander plek en wyse mag plaasvind as in Potchefstroom. 'n Belangrike punt in hierdie opsig is dat die teologiese opleiding onder die toesig van die Kuratore van die TSP bly en dat die opleiding kragtens die roeping van die professore (KO Art 2, 18) die verantwoordelikheid van die beroepe professore bly.

Kerkorde Artikel 8 - By Sinode 2015 (Acta 2015:291-303) het 'n beswaarskrif teen die prosedure wat by Sinode 2012 (Acta 2012:500-502) vir Kerkorde Artikel 8 goedgekeur is, gedien. Slegs een van die beswaargronde het geslaag, naamlik die beswaar teen die prosedure dat 'evalueringslas van die kerke na die TSP (Senaat en Kuratore) verskuif het' (vgl. Acta 2015:301). Die prosedure, wat deur die beswaarskrif voorgestel is, is na die Kuratore verwys om aan te pas en 'in ooreenstemming met die Kerkorde en Sinodebesluite, 
as riglyn aan die kerke deur te gee'. Die Kuratore het die tersaaklike prosedure deeglik ondersoek en 'n enkele wysiging aangebring. Die bepaling is gewysig om soos volg te lui:

Indien die Kerkraad oordeel dat die aansoek meriete het, word die KO, Art 8 aansoek deur die aansoeker met volledige motivering soos Art 8 beskryf tesame met' $n$ aanbeveling van die kerkraad by die TSP ingedien. (Acta 2018:24.3)

Die woorde: 'Dit sal verstandig wees indien die kerkraad ook die advies van die klassis mbt die KO Art 8 aansoek vra' wat in hakies gevolg het, is geskrap. Hierdie wysiging was daarop gemik dat die inisiatief in die toepassing van Kerkorde Artikel 8 by die kerkraad tereg moes kom en nie aan die klassis of selfs aan die TSP oorgedra word nie (Acta 2018:24.3).

Kerkorde Artikel 9 - Sinode 1970 het besluit om die praeparatoir [voorbereidende eksamen] saam te voeg met die kandidaatseksamen, wat studente ná hulle studies aan die Teologiese Skool Potchefstroom aflê (Acta 1970:122-128). Die Sinode het geoordeel dat dit nie nodig is om 'n akademiese eksamen én twee kerklike eksamens, soos Kerkorde Artikel 4 bepaal, af te lê nie. Daar word dus sedert 1970 tussen 'n kandidaatseksamen en 'n kerklike eksamen onderskei. Die fokus by die kandidaatseksamens is op die akademieswetenskaplike toerusting en kennis van die kandidate. Die kerklike eksamen fokus dan op die beroepbaarstelling van die kandidate. Daarby mag die toelatingsaspek van die eksamen nie uit die oog verloor word nie, maar dit dien alles saam in een kerklike eksaminering (vgl. Spoelstra 1989:46-48). Die eksamen fokus primêr op 'n evaluering van die kandidaat se leer en lewe. Die Sinode het egter nie die kerkordelike bepaling oor die praeparatoir en die peremptoir-eksamens verander nie. Die Sinode het geoordeel dat die besluit nie die wese van die kerkorde artikel verander het nie, maar slegs die toepassing daarvan (Acta 1970:127).

Sinode 1970 het verder besluit dat die riglyne vir die afneem van twee kerklike eksamens behou word. Streeksinodes kan dit in werking stel wanneer hulle dit nodig ag. Daarom is die bepaling van die twee kerklike eksamens nie uit die kerkorde verwyder nie, maar behou om wanneer nodig toegepas te word. Sinode 2012 het 'n prosedure goedgekeur waarvolgens 'n Artikel 9 aansoek hanteer word. Vanweë die hoeveelheid aansoeke die laaste jare, was die algemene mening dat dit sinvol sou wees om die prosedure uit te brei. Van die kant van die Kuratore is daar voorgestel dat 'die kerke voortaan die preparatoir en peremptoir-eksamens as selfstandige eksamens afneem om verder steeds met groot versigtigheid uitvoer aan die bepalings van KO, Art 9 te gee' (Acta 2018:24.4). In die beredenering van die rapport, is die tersaaklike agtergrond oor die besluit van 1970 egter uitgelaat. In werklikheid aktiveer Sinode 2018 se besluit die besluit van 1970 om sodoende met groot 'versigtigheid' aan die eis van Kerkorde Artikel 9, uitvoering te gee. Die prosedure wat tans geld, bepaal dat die aansoeker dus eers die nodige colloquia aan die TSP voltooi en daarna die bogenoemde twee kerklike eksamens suksesvol aflê voordat hy beroepbaar gestel kan word. Die kerke het immers die verantwoordelikheid om oor die roeping te oordeel; geen ander instansie naas die kerke het die bevoegdheid om oor die kansel (die verkondiging van die Woord) te waak en persone daartoe toe te laat nie.

Prosedure Artikel 4, 8, 9 - Uit die bogenoemde beswaarskrif, maar ook uit die hantering van die prosedures tydens Sinodes 2015 en 2018 blyk dit dat daar moontlik 'n misverstand oor die prosedures, wat betref Artikels 4, 8, en 9, kan bestaan. Die bogenoemde beswaarskrif het ten doel gehad om te verhoed dat die evalueringslas van die kerke na die TSP verskuif. In die beredenering van die saak tydens die Sinode is daar ook meermale daarna verwys dat die prosedure wat voorgestel word by die Kuratore tuishoort en nie by die kerke nie. Daarmee is waarskynlik bedoel dat die Kuratore die prosedure vir hulle eie hantering van tersaaklike aansoeke ontwikkel het. Dit skep egter verwarring. Sou die aansoeke moontlik op 'n ander manier hanteer kon word as dat 'n aansoeker hom noodwendig tot die Senaat en die Kuratore wend? 'n Probleem met die beswaarskrif is dat dit nie in ag geneem het dat die Teologiese Skool die skool van die kerk en vir die kerke is nie. Indien 'n saak na die TSP verwys word, word dit nie na 'n instansie verwys wat buite die kerk lê nie. Die kerke self, die TSP en die Kuratore tree as 'n eenheid op.

Die Sinode van 1869 het in hierdie verband die volgende besluite geneem:

Nu ere ene Theologische School wordt opgerigt zou de gedachte of vraag kunnen ontstaan: of eene gemeente in het beroepen nu ook gehouden is hare keus te bepalen alleen bij gepromoveerden aan deze school. De Synode verklaart zich duidelijk op dit punt: Dat de gemeenten hare eigendommelijke vrijheid in dezen behouden, gelijk zij die tot hier toe hebben bezeten en uitgeoefend. Maar de toelating tot de $\mathrm{H}$. bediening moet elk deelachtig worden als door deze Synode is bepaald, n.l. door het collegie der Curatoren op de in deze Synode voorschrevene wijze. (Acta 1869:29, Art. 118)

Die 'voorgeskrewe' wyse waarvan daar in die bogenoemde besluit melding gemaak word, verwys na Artikel 84 van die notule waar Kerkorde Artikel 4 aan die orde gestel word. Sinode 1869 het soos volg besluit:

Wordt besloten dat er vooreerst voor proponenten één beslissend examen zal afgenomen worden door de collegie van Curatoren, zoo als dit tot nu toe door de Synode is gedaan.

Bij deze bepaling wil de vergadering evenwel art. 8 der Dordsche Kerkorde in 't bijzonder onder het ooh gehouden hebben, evenwel er bij bepalende, dat indien iemand zich volgens dit artikel aanmeldt, hij met eene aanbeveling der algemeene vergadering waaronder hij behoort, zal komen tot het collegie der Curatoren, die over zijn al of niet toelating zullen beslissen. (Acta 1869:22, Art. 118)

Uit hierdie besluite blyk dat dit wel in die geskiedenis van die kerke gebeur het dat die finale besluit oor toelating tot die bediening selfs aan die Kuratore toevertrou is. Alle kerke het 'n belang by die toelating van ' $n$ kandidaat tot die diens van 
die Woord (KO Art 4). In die beginjare van die kerke was die Kuratore dus in ' $n$ posisie om die kerke se verantwoordelikheid na te kom. Dit plaas die toelating nie buite die bevoegdheidsfeer van die kerke nie, maar wys in die omstandighede van 'n jong kerk op 'n spesifieke toepassing van die beginsel van kerklike toelating. Die Kuratore is in wese 'n eiesoortige kerklike vergadering (Acta 1982:60-68, 1985:534-543, 1988:531-541). Daar is geen prinsipiële beswaar daarteen dat die Kuratore besluit oor toelating tot die bediening van die Woord in spesifieke omstandighede nie. Die kerke bly steeds vir die toelating tot die bediening verantwoordelik omdat die onderskeie Streeksinodes tans verantwoordelik is vir die beroepbaarstelling van studente uit daardie ressort. Die prosedures vir die toelating tot die bediening van die Woord, spesifiek wat betref Kerkorde Artikels 8 en 9 , het in dié lyn verder ontwikkel. Die bedoeling is nie dat die prosedures slegs vir die interne gebruik van die Kuratore bedoel is nie. Dit gee veel eerder uitdrukking aan die wyse waarop die kerke ordelik aan bestaande sinodebesluite oor die toelating tot die bediening van die Woord (KO Art 4, 8, en 9) uitvoer gee.

\section{Die Kuratore en die Senaat}

Die Prospektus van die Teologiese Skool Potchefstroom (PTSP; 2017) is 'n samevatting van sinodebesluite en praktiese reëlings oor die diens van die professore, die Kuratore en die kandidaatstudente, dit wil sê die studente wat met die oog op die toelating tot die bediening van die Woord in die GKSA studeer. In hierdie opset funksioneer die TSP-Senaat nie as 'n selfstandige entiteit nie. Die fokus is nie op die 'instelling', die institusionele aspek van die Senaat, nie, maar op die uitvoering van die vierde diens en die sinvolle koördinering van die nodige aspekte daarvan (vgl. Du Plooy 2014). By wyse van die vierde diens word studente in die teologie opgelei. Van hierdie studente is ook kandidaatstudente. Daarin lê ' $n$ belangrike onderskeid tussen die diens van die professore en die verantwoordelikheid van die Kuratore. Die Kuratore is nie verantwoordelik vir studente-opleiding nie, maar hou wel toesig oor die opleiding. Die verhouding tussen die Kuratore en die professore (Senaat) kan moontlik na analogie van die verhouding tussen 'n raad van die universiteit en die bestuur van 'n universiteit verduidelik word. Die Kuratore vervul in dié opsig die funksie van 'n raad; hulle is verantwoordelik vir die beheer (governance) van die instelling, maar die beroepe professore, wat in die Senaat saamkom, is vir die bestuur (management) van die TSP verantwoordelik (vgl. Prospektus 2014; Hoofstuk 3, 5). Die Senaat TSP ontvang volgens die prosedure van 2012 (Acta 2012:500-502) die verantwoordelikheid om, in die geval van Artikels 8 en 9 aansoeke, 'n evaluering van die kandidaat se teologiese insig en kennis te doen. Daaraan is daar niks vreemd nie. Die professore is kragtens hulle roeping besig met opleiding van studente en op hoogte van die standaard en vereistes waaraan enige bedienaar van die Woord behoort te voldoen. Die verantwoordelikheid om die kerke oor die toelating van persone in terme van Artikels 8 en 9 te adviseer, berus by die professore.

\section{Slot}

'n Bedienaar van die Woord word tot 'n unieke, dit is 'n eiesoortige, orde vir die vervulling van sy roeping toegelaat. Die eksegeties-dogmatiese voorveronderstellings van die diens, die wese en die uitvoering daarvan is onmiskenbaar. Dit word ook as sodanig in verskeie jurisdiksies aanvaar en daarvolgens ingerig en beoordeel. ${ }^{1}$ Die kerkorde reël in dié opsig 'n Woord-bepaalde verhouding op grond van die roeping van 'n persoon. Dit het nie die aard van 'n arbeidsregtelike verhouding in wêreldlike sin nie. Met inagneming van die unieke situasie wat die onderskeie kerkorde artikels reël, word die roeping en die gawes wat die vereistes vir die toelating tot die diens daarstel aan die TSP ontwikkel en geëvalueer. Die verantwoordelikheid berus dus by die professore om die kerke te adviseer oor die toelating van 'n persoon tot die bediening van die Woord. Tydens die colloquium word van die persoon verwag om daarvan rekenskap te gee dat hy op dieselfde vlak is as wat van 'n finalejaar kandidaatstudent verwag word - die nodige insig in die Woord toon om op 'n konstante basis die Woord suiwer te kan bedien. In terme van Artikel 9 aansoeke is daar die geleentheid om oneffenhede in die leer en lewe wat tussen die vorige kerkverband en die GKSA sou kon bestaan onder die loep te neem en enige vrae daaroor op te klaar. Indien daar enkele tekortkominge by 'n persoon sou wees, kan dit moontlik by wyse van enkele colloquiums ondervang word. Die bedoeling is egter nie om 'n opleiding gelykstaande aan dié van kandidaatstudente van Artikel 8 en 9 aansoekers te vereis nie. Indien dit sou blyk dat daar fundamentele tekortkominge in die mondering van ' $n$ aansoeker is, behoort hy geadviseer te word om vir die nodige studie in te skryf (KO Art 4). Sodanige besluit, met die nodige motivering, word aan die Kuratore gekommunikeer. Uit hierdie toepassings van Artikels 8 en 9 blyk die unieke, godsdienstige aard van die verhouding tussen die bedienaar van die Woord en die gemeente.

\section{Literatuurverwysings Mededingende belange}

Die outeur verklaar dat hy geen finansiële of persoonlike verbintenis het met enige party wat hom nadelig kon beïnvloed het in die skryf van hierdie artikel nie.

\section{Literatuurverwysings}

Acta, Kyk Gereformeerde Kerke.

Biesterveld, P. \& Kuyper, H.H., 1905, Kerklijke handboekje bevattendede Bepalingen der Nederlandsche Synoden en andere stukken van betekenis voor de Regeering der Kerken, Kampen.

Bohatec, J., 1961, Calvins Lehre von Staat und Kirche mit besonderer Berücksichtigung des Organismusgedankens, Scientia, Aalen.

Bouwman, H., 1970, Gereformeerd Kerkrecht, deel 1, Kok, Kampen.

Calvyn, J., 1991, Institusie van die Christelike Godsdiens, boek IV, vert. H.W. Simpson, Calvyn Jubileum Boekefonds, Potchefstroom.

De Gier, K., 1989, De Dordtse kerkorde Een praktische verklaring, Den Hertog, Houten.

1.vgl. in die opsig, byvoorbeeld, die situasie in die Verenigde Koninkryk met inagneming van ontwikkelinge wat in die laaste jare daar plaasgevind het; vgl. ook Duitsland, Nederland en Frankryk. 'n Bron waarvan daar al verskeie uitgawes in Duitsland, Nederland en Frankryk. ' $n$ Bron waarvan daar al verskeie uitgawes in
verskeie Europese tale verskyn het en wat die tersaaklike gegewens oorsigtelik aanbied, is byvoorbeeld Robbers (ed. 2005). 
DKO, Kyk Biesterveld, P. Du Plooy, A le R., 1992, 'Calvyn oor die koninkryk van God en die staat', Hervormde Teologiese Studies 48(3 \& 4), 759-771.

Du Plooy, A.L., 2014, 'Calvyn se vierde diens, die doktoreamp, en artikel 18 van die kerkorde van Dordrecht 1618 en 1619: 'n Kritiese refleksie', In die Skriflig 48(2), Art. \#1760, 1-11. https://doi.org/10.4102/ids.v48i2.1760

Gereformeerde Kerke in Suid-Afrika, 1869, Handelingen van de vierde Algemeene Synodale Kerkvergadering zamengesteld uit al de Gereformeerde Kerken van ZuidAfrika vergaderd te Potchefstroom den 17den Mei, 1969, en volgende Dagen Solomon, Kaapstad.

Gereformeerde Kerke in Suid-Afrika, 1882, Handelingen van de vierde Algemeene Synodale Kerkvergadering zamengesteld uit al de Gereformeerde Kerken van Zuid-Afrika vergaderd te Potchefstroom den 10den April tot den 24sten April, en volgende Dagen, Solomon, Kaapstad.

Gereformeerde Kerke in Suid-Afrika, 1970, Handelinge van die sewe-en-dertigste sinodale vergadering van die Gereformeerde Kerk in Suid-Afrika in sitting byeen te Potchefstroom op 21 Januarie 1970 en volgende dae, Potchefstroom Herald, Potchefstroom.

Gereformeerde Kerke in Suid-Afrika, 1982, Handelinge van die een-en-veertigste Sinode te Potchefstroom op 6 Januarie en volgende dae, Potchefstroom Herald Potchefstroom.

Gereformeerde Kerke in Suid-Afrika, 1985, Handelinge van die twee-en-veertigste Nasionale Sinode in Potchefstroom op 8 Januarie en volgende dae, Potchefstroom Herald, Potchefstroom.

Gereformeerde Kerke in Suid-Afrika, 1988, Handelinge van die drie-en-veertigste Nasionale Sinode te Potchefstroom 5 Januarie 1988 en volgende dae, Potchefstroom Herald, Potchefstroom.

Gereformeerde Kerke in Suid-Afrika, 2006, Handelinge van die nege-en-veertigste Nasionale Sinode te Potchefstroom op 4 Januarie 2006 en volgende dae en derde Addendum van die Emeritaatsversorgingstrust, V\&R Drukkers, Pretoria.

Gereformeerde Kerke in Suid-Afrika, 2012, Handelinge van die Tweede Algemene Sinode te Potchefstroom op 4 Januarie 2012 en volgende dae, V\&R Drukkers, Pretoria.

Gereformeerde Kerke in Suid-Afrika, 2015, Handelinge van die derde Algemene Sinode gehou te Potchefstroom op 6 Januarie en volgende dae, V\&R Drukkers, Pretoria.

Gereformeerde Kerke in Suid-Afrika, 2018, Handelinge van die vierde Algemene Sinode te Potchefstroom op 12 Januarie en volgende dae, V\&R Drukkers, Pretoria.

Jansen, J., 1952, Korte verklaring van de kerkenordening, 3e druk, Kok, Kampen.

Kerkordeboekie van die Gereformeerde Kerke in Suid-Afrika, 1998, Admin. Buro van die Gereformeerde kerke in Suid-Afrika, Potchefstroom.

KO, Kyk Kerkordeboekie.

Kruger, L.S., Du Plessis, H.L.M., Spoelstra, B. \& Spoelstra, T.T., 1966, Handleiding by die kerkorde van die Gereformeerde Kerke in Suid-Afrika, Pro Rege, Potchefstroom.

Nederduitse Gereformeerde Kerk (NGKO), 2011, Die Kerkorde, sn, sl.
Plomp, J., 1969, De kerklijke tucht bij Calvijn, Kok, Kampen.

Pont, A.D. (red.), 1981, Die historiese agtergrond van ons kerklike reg, deel 1, HAUM, Pretoria.

Prospektus van die Teologiese Skool Potchefstroom van die Gereformeerde Kerke in Suid-Afrika, 2014, V\&R Drukkery, Pretoria.

Robbers, G. (ed.), 2005, Staat und Kirche in der Europäischen Union, European Consortium for Church State Research, Nomos.

Smit, C.J., 1984, God se orde vir sy kerk, NG Kerkboekhandel, Pretoria.

Smit, C.J., 1997, 'A governing of the heart mainly as seen by John Calvin', in W.H. Neuser \& H.J. Selderhuis (eds.), Ordenlich und Fruchtbar Festschrift für Willem van't Spijker, Groen en Zoon, Leiden.

Smit, J., 2001, 'n Gereformeerd-kerkregtelike beoordeling van die predikant se verbintenis aan die plaaslike kerk', Th.M.-verhandeling, Fakulteit Teologie, PU vir $\mathrm{CHO}$, Potchefstroom.

Smit, J. 2005. 'Die regsposisie van die gereformeerde predikant in die godsdiensneutrale staat van Suid-Afrika', PhD-tesis, Fakulteit Teologie, PU vir CHO, Potchefstroom.

Smit, J., 2018, 'The decline of reformed church polity in South Africa', In die Skriflig 52(3), a2309. https://doi.org/10.4102/ids.v52i3.2309

Spoelstra, B., 1989, Gereformeerde kerkreg en kerkregering: Handboek by die Kerkorde Hammanskraalse Teologiese Skool van die Gereformeerde Kerke in Suid-Afrika, Hammanskraal.

Strauss, P., 2016, 'Ouderlinge met preekvergunning: 'n Herlewing van Dordtse Kerkorde artikel 8?', In die Skriflig 50(1), a2092. https://doi.org/10.4102/ids.v50i1.2092

Van Coller, E.H., 2013a, 'Geloofsinstellings en prosedurele billikheid: Die toepassing van die reëls van natuurlike geregtigheid by die prosedures, besluite en optredes van geloofsinstellings', Recht Religie en Samenleving/Droit, Religion et Société/ Law, Religion and Society (RRS) 2013(1), 71-106.

Van Coller, H., 2013b, 'Religious institutions and fundamental rights: Applicability, interaction and limitations in South Africa', in W.C. Durham, Jr., C. Cianitto, S. Ferrari \& D.D. Thayer (eds.), Law, religion, constitution: Freedom of religion, equal treatment, and the law, pp. 209-255, Ashgate, Surrey.

Van der Linde, G.P.L., 1983, Die Kerkorde - 'n verklaring van die Gereformeerde kerkorde, Potchefstroomse Teologiese Publikasies, Potchefstroom.

Van't Spijker, W., 1990, 'Het presbyteriale-synodale stelsel', in W. Van't Spijker, W. Balke, K. Exalto \& L. van Driel (eds.), De Kerk: Wezen, weg en werk van de kerk naar reformatorische opvatting, pp. 326-338, Uitgeverij De Groot Goudriaan, Kampen.

Van't Spijker, W., 1991, “"Extra nos” en "In nobis” bij Calvijn in pneumatologisch licht', in C. Augustijn, W.H. Neuser \& H.J. Selderhuis (eds.), Geest, Woord en Kerk: Opstellen over de gesckiedenis van het gereformeerd protestantisme, pp. 114-132, Kok, Kampen

Van't Spijker, W., 2004, Bij Calvijn in de Leer Een handeleiding bij de Institutie, De Hertog, Houten.

Visser, J. 1999, Die kerkorde in praktyk, EFJS Drukkers, Orkney. 